I I 1

International Journal of

Educational Psychology

\section{Hipatia Press}

www.hipatiapress.com

Instructions for authors, subscriptions and further details:

http://ijep.hipatiapress.com

\title{
Truth, Beauty, and Goodness Reframed. Educating for the Virtues in the Twenty-First Century
}

Silvia Molina ${ }^{1}$

1) Department of Pedagogy, University Rovira i Virgili, Spain.

Date of publication: February, 24th 2012.

To cite this review: Molina, S. (2012). [Review of the book Truth, Beauty, and Goodness Reframed. Educating for the Virtues in the Twenty-First Century, by Howard Gardner], International Journal of Educational Psychology (IJEP), 1(1), 70-72. DOI: 10.4471/ijep.2012.05

To link this review: http://dx.doi.org/10.4471/ijep.2012.05

\section{PLEASE SCROLL DOWN FOR ARTICLE}

The terms and conditions of use are related to the Open Journal System and to Creative Commons Non-Commercial and Non-Derivative License. 
IJEP - International Journal of Educational Psychology Vol. 1 No. 1

February 2012 pp.70-72.

\section{Review}

Howard Gardner. (2011). Truth, Beauty, and Goodness Reframed. Educating for the Virtues in the Twenty-First Century. New York: Basic Books.

Three classical virtues that have guided human thoughts and behavior through history, truth, beauty and goodness, are the focus of Howard Gardner's book. Gardner discusses the role and importance of these virtues in current society, which has seen important transformations since these virtues, "the trio", were first conceptualized. The postmodernism and the advent of the digital media are two central events that have shaped societies in the last decades. In this new context, the classical virtues need to be "reframed", and reframing the classical virtues in society entails rethinking how to educate on these three virtues.

Postmodern theories questioned the possibility to ascertain truth as well as its value for human existence, arguing that it is only an expression of power. These views also treated beauty as irrelevant and have been skeptical about goodness. The media technologies, in turn, challenge the ideas of truth, goodness and beauty, as they offer great amounts of information, with different levels of rigor and sometimes contradictory, offer different and new ways of relating to others, and allow mew forms of creating, acceding, and storing works of art.

Despite this challenging picture, Gardner believes that the core characteristics of truth, beauty and goodness can be preserved and defends the usefulness and the deep meaning that the three virtues have for people today. He reviews the current status of the classical virtues from a multidisciplinary perspective, contributing with reflections from history, biology, psychology, sociology or anthropology. From this

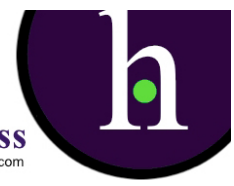


review, he concludes that the search of truth is today possible if we base for people today. He reviews the current status of the classical virtues from a multidisciplinary perspective, contributing with reflections from history, biology, psychology, sociology or anthropology. From this review, he concludes that the search of truth is today possible if we base on scholarly disciplines and professional crafts, which have provided empirical contrastable knowledge through history. As regards goodness, he emphasises the need to differentiate between the "neighborly morality", which characterises good relations with others, and "the ethics of roles", which refers to being a "good worker" or a "good citizen" in changing societies with increasing new situations to deal with, new problems to solve and new forms of relation. Finally, he contends that beauty should be formulated as the personal experience caused of an object which is interesting, its form is memorable and invites further encounters.

The author acknowledges that the three virtues are qualitative different and that they have different histories, being the history of truth "convergent and confirmatory", the history of beauty "divergent", unpredictable and more dependable on personal experiences, and the history of goodness having one consolidated part -the neighborly morality- and another more recent - the ethics of roles-. Furthermore, they are also different in terms of their relevance for life, being beauty the less determinant for survival. Nonetheless, Gardner clearly supports the importance of the three virtues, as he understands the experience of beauty as one main reason for living once survival is granted. In this regard, he considers: "The trio of virtues, while unquestionably in flux and under attack, remain essential to the human experience and, indeed, to human survival. They must not and will not be abandoned" (p.13). It is noteworthy the capacity Gardner attributes to persons in the development of "the trio". Gardner gives to individuals, working alone or together, the power to achieve desirable goals, starting from the premise that: "what is distinctly human is our capacity to change, or to transcend, whatever traits and inclinations we may have as initial endowment, courtesy of evolution" (p.15).

For this reason, he offers an educational approach to ensure the pass of these values to new generations, and also to improve the way in which adults can reconceptualise the virtues in this new context. 
72 Silvia Molina - Truth, Beauty, and Goodness Reframed

tion synergies are noted as powerful to achieve these objectives: while the accumulated experience of old people can help young persons being introduced in values with a long tradition, they can introduce their elders in new realities such as the media, which provide new experiences and contexts to reframe them.

What makes Truth, Beauty, and Goodness Reframed an essential book for teachers, educators and families, is being a relevant and meaningful work for today based on values that have always been on the agenda.

Silvia Molina Roldán

University Rovira i Virgili

silvia.molina@urv.cat 